ORIGINAL ARTICLE

\title{
The effect of antifungal and Ago and Zno nanoparticles on Trichophyton mentagrophytes
}

\author{
HIBA YOUNIS KHALAF ${ }^{*}$, HALA ABDULKHALIQ AWADH², HADEEL MIZHER YOUNIS ${ }^{3}$, NAWAR ALI JASIM ${ }^{4}$, AND KASIM \\ SAKRAN ABASS ${ }^{5}$ \\ ${ }^{1}$ Department of Microbiology, College of Veterinary Medicine, University of Tikrit, Tikrit, Iraq \\ ${ }^{2}$ Department of Biology, College of Science, University of Tikrit, Tikrit, Iraq \\ ${ }^{3}$ Department of Basic Sciences, College of Dentistry, University of Tikrit, Tikrit, Iraq \\ ${ }^{4}$ Department of Pathology, College of Veterinary Medicine, University of Tikrit, Tikrit, Iraq \\ ${ }^{5}$ Department of Anatomy and Histology, College of Veterinary Medicine, University of Kirkuk, Kirkuk, Iraq \\ ${ }^{*}$ Corresponding authors: email: hibamicrobiology@tu.edu.iq
}

\begin{abstract}
This study aimed to determine the main species of dermatophytes which caused skin infection and effect of antifungal and Ago and Zno nanoparticles on them. The result of this study showed that out of 80 sample, 54 sample were positive to fungal isolation with ratio $67.5 \%$. and according to culture and PCR results \%38.8 of isolated type belong to Trichophyton mentagrophytes. Trichophyton mentagrophytes resistant to Nystatin and Fluconazole while sensitive to Griesofulvin, Clotrimazole and Flucytosin. MIC of Ago and Zno nanoparticle against Trichophyton mentagrophytes were 250 and $275 \mu \mathrm{g} / \mathrm{ml}$ while MFC were 275 and $300 \mu \mathrm{g} / \mathrm{ml}$ respectively. Results of RAPD PCR showed that both Ago and Zno nanoparticle effect in genetic material of Trichophyton mentagrophytes
\end{abstract}

Key words: Trichophyton mentagrophytes, nanoparticle, RAPD PCR

\section{INTRODUCTION}

Skin is first line define against infection, it protects the body from external physical, chemical and biological effects, as well as it has physiological functions such as balancing the body temperature, its complex system formed about $15 \%$ from total body weight (1).

Dermatophytes belong to deuteromycota fungi, it consist from three genus which are: Microsporum, Trichophyton and Epidermophyton. Its classified according to sources of infection in to: Anthropophilic species, Zoophilic species and Geophilic species (2). Dermatophytosis is most common types of skin infection, these group of fungi called keratophilic, it have Keratinase which help them in use of keratin as source of protein (3).

Clinical of Dermatophytes infection can be classified according anatomical location of infection in: Tinea capitis, Tinea ungium, Tinea corporis, Tinea manum, Tinea barbae, Tinea pedis, Tinea faieci and Tinea cruris (4).

Similarities between fungi cell and host cell and development of fungi resistant against antifungal drugs lead to difficulty in treatment of mycotic infection (5).

Nanoparticles is one alternatives treatment to antifungal, which is a particles in size 10-100 nanometer,
Manufactured by Down-Up Fabbrication or Up- Down Fabbrication, have different physical and chemical properties in compare with its origin, act as antifungal and a microbial agents (6).

\section{MATERIAL AND METHODS}

Sample collection and fungal diagnosis: (80) pathological skin samples were collected from outpatient clinics Under the supervision of dermatologists. The samples direct cultivation in Sabouraud dextrose agar and incubated at $25-30{ }^{\circ} \mathrm{C}$ for 7 days. After colony development, one colony selected for phenotypic examination and Microscopic examination applied according to (7) and a group of biochemical tests were applied (Hair penetration test, Urease enzyme test and Protease production test) according to (8).

PCR test for confirmation diagnosis of Trichophyton mentagrophytes

A- DNA extraction : DNA was extracted according to (7).

B- DNA amplification mixture: as in Table (1)

C- Thermocycler program: as in table (2) according to (9)

Table (1) Compounds used in preparation of Reaction Mixture

\begin{tabular}{|c|c|c|}
\hline Compounds used in preparation of Reaction Mixture & Reference & Amount \\
\hline $\begin{array}{l}\text { Taq PCR Master Mix KIT (Qiagen, Germany) Which contain Taq DNA } \\
\text { Polymerase (2.5 Unit), PCR Buffer with } 3 \mathrm{mM} \text { MgCL2, } 200 \mu \text { MdNTP }\end{array}$ & 3 & 25 \\
\hline Panderm_F(5'GAAGAAGATTGTCGTTTGCATCGTCTC3 & \multirow{2}{*}{$\begin{array}{l}7 \\
\text { Out product size } 336 \mathrm{bp}\end{array}$} & 0.3 from 100pM Solution. \\
\hline Panderm_R(5'CTCGAGGTCAAAAGCACGCCAGAG3' & & 0.3 from 100pM Solution. \\
\hline DNA Template & Samples & 3 \\
\hline DNA free water (Qiagen, Germany) & 8 & 21.4 \\
\hline Total & & 50 \\
\hline
\end{tabular}

- $\quad$ Antifungal sensitivity test: applied by disc methods against Nystatin , Griesofulvin , Fluconazole, Clotrimazole, Flucytosin and according to (10).

- $\quad$ Minimum inhibitory concentration (MIC)and Minimum fungicidal concentration (MFC) of nanoparticles (Ago and Zno) : applied by tube methods according to (11). with final nanoparticles concentration (100,200, 225, $250,275,300,325,350 \mu \mathrm{g} / \mathrm{ml}$ ).

Study effect of nanoparticles on genetic materials of Trichophyton mentagrophytes by RAPD PCR: 
A- DNA was extracted according to (12).

B- Preparation of RAPD-PCR reactions according to (11), were performed using the (GoTaq ${ }^{\circledR}$ G2 Green master mix.

C- Thermocycler program: as in Table 3.

Table (2): showed thermocycler program

\begin{tabular}{|l|l|l|l|}
\hline Stage & Temperature & Time & $\begin{array}{l}\text { No. of } \\
\text { cycles }\end{array}$ \\
\hline $\begin{array}{l}\text { First Denaturation } \\
\text { step }\end{array}$ & $95 \mathrm{c}^{\circ}$ & 3 mints & 1 cycle \\
\cline { 1 - 3 } Denaturation step & $94 \mathrm{c}^{\circ}$ & $45 \mathrm{sec}$. & \multirow{2}{*}{35 cycles } \\
\cline { 1 - 2 } $\begin{array}{l}\text { Primer-annealing } \\
\text { step }\end{array}$ & $56 \mathrm{c}^{\circ}$ & $45 \mathrm{sec}$. & \\
\cline { 1 - 2 } DNA extension step & $72 \mathrm{c}^{\circ}$ & $1 \mathrm{mint}$ & \\
\hline Final DNA extension & $72 \mathrm{c}^{\circ}$ & $\begin{array}{l}10 \\
\text { mints }\end{array}$ & \\
\hline End Temperature & $4 \mathrm{c}^{\circ}$ & ----------- & --------- \\
\hline
\end{tabular}

Table (3):Thermocycler program

\begin{tabular}{|c|c|c|c|}
\hline Step & Temperature $\left(\mathrm{C}^{\circ}\right)$ & Time & $\begin{array}{l}\text { No. of } \\
\text { cycles }\end{array}$ \\
\hline Initial denaturation & 95 & $4 \mathrm{~min}$ & 1 \\
\hline Denaturation & 92 & 30sec. & \multirow{3}{*}{40} \\
\hline Annealing & 36 & $45 \mathrm{sec}$. & \\
\hline Extension & 72 & $45 \mathrm{sec}$. & \\
\hline Final extension & 72 & $5 \mathrm{~min}$ & 1 \\
\hline
\end{tabular}

D- Primers used in RAPD PCR as in table (4)

Table (4): Primers used in RAPD PCR

\begin{tabular}{|l|l|l|}
\hline No & Primer code & Nucleotide sequence 5 to 3 \\
\hline 1 & OP V-20 & CAGCATGGTC \\
\hline 2 & OP Q-02 & TCTGTCGGTC \\
\hline 3 & OP G-05 & CTGAGACGGA \\
\hline 4 & OP P-04 & GTGTCTCAGG \\
\hline 5 & OP U-12 & TCACCAGCCA \\
\hline
\end{tabular}

\section{RESULTS}

A- Result of fungal isolation :

Out of 80 sample, 54 sample were positive to fungal isolation with ratio $67.5 \%$. Table 5 .

Table (5): Number and ratio of fungal isolation

\begin{tabular}{|l|l|l|l|}
\hline Gander of patient & $\begin{array}{l}\text { Number of } \\
\text { sample }\end{array}$ & $\begin{array}{l}\text { Number of } \\
\text { positive case }\end{array}$ & Ratio \\
\hline Male & 43 & 31 & $72.0 \%$ \\
\hline Female & 37 & 23 & $62.1 \%$ \\
\hline Total & 80 & 54 & $67.5 \%$ \\
\hline
\end{tabular}

B- from table (6) show that's highest infection case was Tinea capitis and lowest was Tinea crusis

Table (6): type of tinea and ratio of fungal isolation

\begin{tabular}{|l|l|l|l|l|}
\hline Type of tinea & \multicolumn{3}{|l|}{ Clinical case } & Isolation \\
\cline { 2 - 5 } & No & $\%$ & No & $\%$ \\
\hline Tinea capitis & 21 & $26.2 \%$ & 16 & $76.1 \%$ \\
\hline Tinea corpis & 19 & $23.7 \%$ & 13 & $68.4 \%$ \\
\hline Tinea manum & 14 & $17.5 \%$ & 8 & $57.1 \%$ \\
\hline Tinea pedis & 11 & $13.7 \%$ & 7 & $63.6 \%$ \\
\hline Tinea faciei & 8 & $10 \%$ & 5 & $62.5 \%$ \\
\hline Tinea ungium & 5 & $6.25 \%$ & 4 & $80.0 \%$ \\
\hline Tinea crusis & 2 & $2.5 \%$ & 1 & $50.0 \%$ \\
\hline Total & 80 & $100 \%$ & 54 & $67.5 \%$ \\
\hline
\end{tabular}

C- Genus and Species of isolated fungi: from table (7) showed that highest isolated species was Trichophyton mentagrophytes (Figure 1 and Figure 2) and lowest isolated species was Epidermophyton floccosum

Table (7):Genus and Species of isolated fungi

\begin{tabular}{|l|l|l|}
\hline Dermatophyte species & Number & Ratio \\
\hline Trichophyton mentagrophytes & 21 & $\% 38.8$ \\
\hline Trichophyton tonsurans & 15 & $\% 27.7$ \\
\hline Trichophyton verrucosum & 3 & $\% 5.5$ \\
\hline Trichophyton rubrum & 3 & $5.5 \%$ \\
\hline Microsporum canis & 6 & $\% 11.1$ \\
\hline Microsporum ferrugineum & 4 & $\% 7.4$ \\
\hline Epidermophyton floccosum & 2 & $\% 3.7$ \\
\hline TOTAL & 54 & $\% 100$ \\
\hline
\end{tabular}

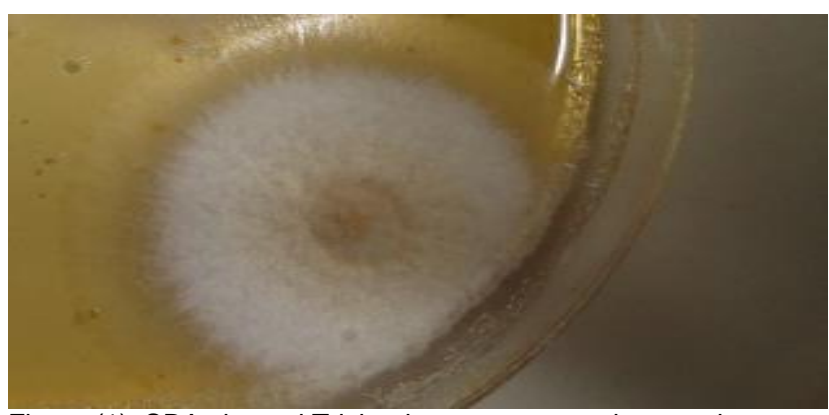

Figure (1): SDA showed Trichophyton mentagrophytes colony

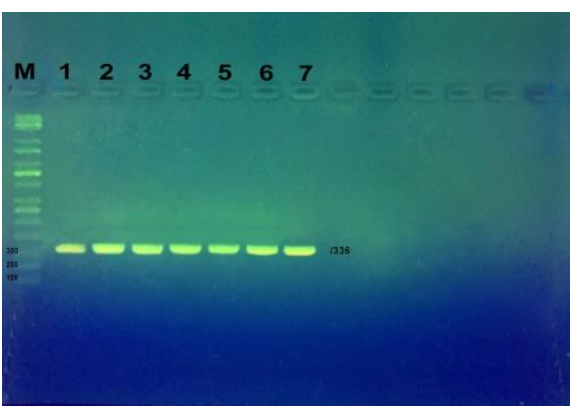

Figure (2): Agarose gel electrophoresis of PCR products. M: 100 bp DNA ladder, lines (1-7) positive result at 336bp for Trichophyton mentagrophytes

D- Result of antifungal sensitivity test: as in table (8). 
Table (8): antifungal sensitivity test

\begin{tabular}{|c|c|c|c|c|c|}
\hline \multirow{2}{*}{$\begin{array}{l}\text { Tnhibition diameter } \\
\text { Zone }(\mathrm{mm}) \\
\text { Isolates }\end{array}$} & \multicolumn{5}{|c|}{ Antifungal agents } \\
\hline & Nystatin & Griesofulvin & Fluconazole & Clotrimazole & Flucytosin \\
\hline Trichophyton mentagrophytes & - & 16 & - & 14 & 16 \\
\hline Trichophyton rubrum & - & 12 & 4 & 12 & 8 \\
\hline Trichophyton.tonsurans & - & 12 & - & 10 & - \\
\hline Trichophyton verrucosum & - & 14 & - & 12 & - \\
\hline Microsporum canis & - & 18 & 8 & 16 & 16 \\
\hline Microsporum ferrugineum & - & 20 & 6 & 18 & 14 \\
\hline Epidermophyton floccosum & - & 16 & - & 12 & 8 \\
\hline
\end{tabular}

Table (9): MIC and MFC of of Ago and Zno nanoparticle against Trichophyton mentagrophytes

\begin{tabular}{|l|l|l|}
\hline \multirow{2}{*}{$\begin{array}{l}\text { Concentration of } \\
\text { nanoparticles }(\mu \mathrm{g} / \mathrm{ml})\end{array}$} & Type of nanoparticles \\
\cline { 2 - 3 } & Ago & Zno \\
\hline 100 & Turbidity/growth & Turbidity/growth \\
\hline 200 & Turbidity/ growth & Turbidity/ growth \\
\hline 225 & Turbidity/ growth & Turbidity/growth \\
\hline 250 & Clear / growth & Turbidity / growth \\
\hline 257 & Clear / sterile & Clear / growth \\
\hline 300 & Clear / sterile & Clear / sterile \\
\hline 325 & Clear / sterile & Clear / sterile \\
\hline 350 & Clear / sterile & Clear / sterile \\
\hline
\end{tabular}

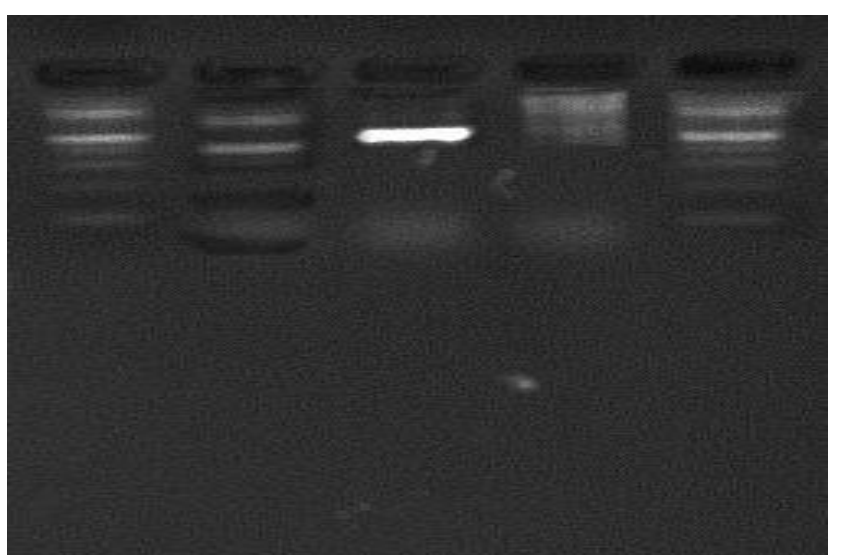

Figure (3): Agarose gel electrophoresis of RAPD- PCR products. lines (1-5) positive result of Trichophyton mentagrophytes with5different primers, before treatment with Nanoparticle

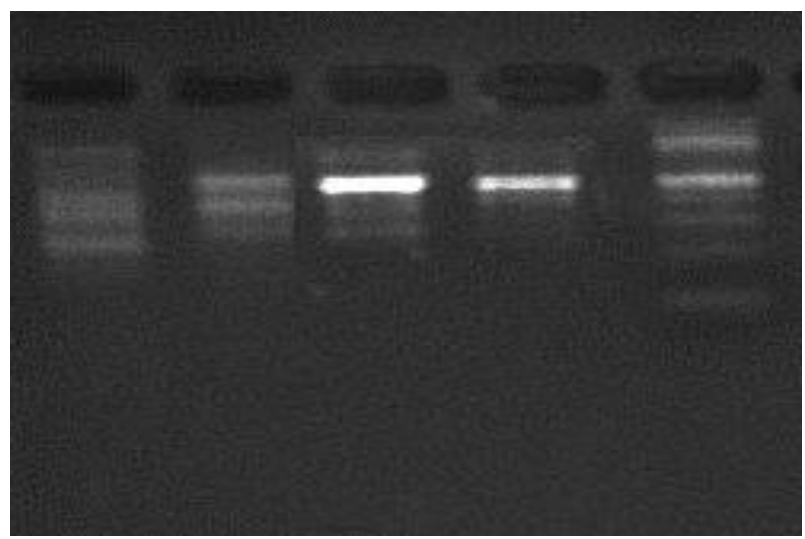

Figure (4): Agarose gel electrophoresis of RAPD- PCR products. lines (1-5) positive result of Trichophyton mentagrophytes with5different primers, after treatment with Ago Nanoparticle

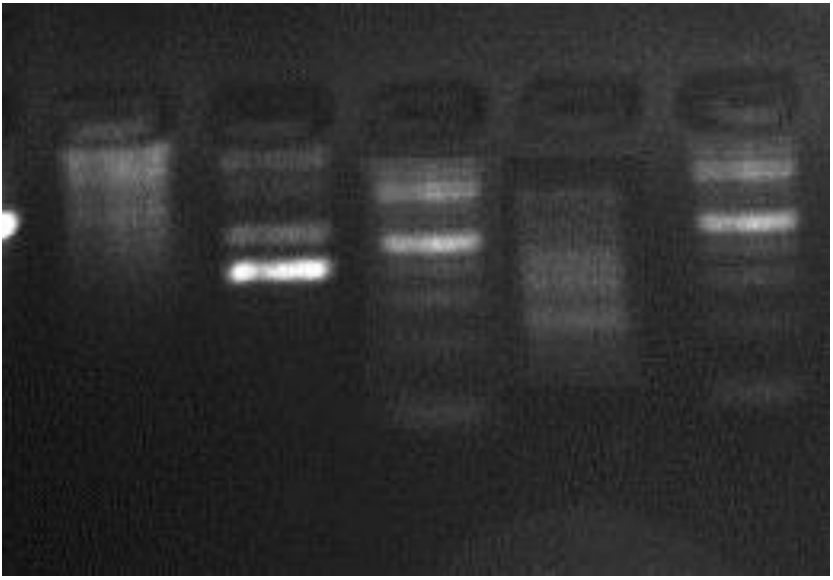

Figure (5): Agarose gel electrophoresis of RAPD- PCR products lines (1-5) positive result of Trichophyton mentagrophytes with5different primers, after treatment with Zno Nanoparticle

E- Result of antifungal activity of nanoparticle(Ago and Zno) against Trichophyton mentagrophytes: from table (9) showed that MIC of Ago and Zno nanoparticle against Trichophyton mentagrophytes were 250 and $275 \mu \mathrm{g} / \mathrm{ml}$ while MFC of Ago and Zno nanoparticle against Trichophyton mentagrophytes were 275 and $300 \mu \mathrm{g} / \mathrm{ml}$ respectively.

F- Result of RAPD PCR test: from figure 3,4,5 showed that both Ago and Zno nanoparticles were effected in genetic materials which showed as appear or disappear and increase or decrease in thickness of bands

\section{DISCUSSION}

The common type of skin diseases were Superficial fungal infections which affecting millions of healthy and immunocompromised people worldwide (13).

$\mathrm{n}$ the current study showed presence of $32.5 \%$ of clinical infected cases were negative to culture that's may be due to take of patient to antifungal drugs or error in transport of sample or culture technique, or due to contamination of sample with other organism or maybe the infected not fungal origin (14). In present study showed that main type of infection were Tinea capitis that's perhaps due to factors related with the community culture, such as Clean the barbers, Free barber tools from the causes of disease.

In current study showed that the dominants fungal isolated type was Trichophyton mentagrophytes that's 
agreement with (15) and disagreement with (16). The dominance of fungal type in compare with other type depend on geographic location, type of samples, season and Community habits.

In this study show high effect of Ago nanoparticles as antifungal and according to RAPD PCR showed effect in genetic materials, that's agreement with (17). Ago nanoparticles have high specific surface area and high fraction of surface atoms in compare silver metal, that's may be gives him the antifungal characteristic (18). The antifungal activity of AgNPs due to their ability to accumulation on fungal membrane of microorganisms, formation of pores which lead to change in permeability of cell wall. Also AgNPs can cause inhibit cellular respiration, DNA replication, and cell division, which result in the loss of cell viability, and lead to cell death (19).

In the current showed obvious effect of Zno nanoparticles on Trichophyton mentagrophytes and according to RAPD PCR showed effect in genetic materials. This agreement with $(20,21,22)$. These activity may be due to electrostatic interaction between negative charge of cell membrane and positive charge of nanoparticles (23). $\mathrm{Zn}$ o have ability to cause damage to the cell membrane directly leads to the leakage of minerals, al may be act as antifungal due to toxic properties of metal oxide NPs, also have ability to bind with thethiol($\mathrm{SH}$ )groups of protein present in the cell wall. This interaction decreases the cell permeability which leads to cell lyses $(24,25,26)$.

Conflict of Interests: The authors of this paper declare that he has no financial or personal relationships with individuals or organizations that would unacceptably bias the content of this paper and therefore declare that there is no conflict of interests.

Source of Funding: The authors have no sources of funding, so it is self-funding research.

Ethical Approve: We declare that the study does not need ethical approval.

\section{REFERENCES}

1. Atlas, M. R.(2005). Handbook of Media for Environmental Microbiology.2nd ed .Taylor \& Francis publisher.New York.U.S.A

2. Barry, A.L.,Gordon, S; Gilbert, J.L, (2000). Quality control limits for broth microdilution susceptibility tests of ten antifungal agents J. Clin. Micro. 38:3457 - 3459.

3. Barry AL, Garcia F \& Trupp LD (1984): Animproved single disc method for testing theantibiotic susceptibility of rapidly growingpathogens. Am J Clin Pathol 53: 149-158.

4. Bordon-Pallier, F., Jullian, N., \& Haesslein, J. L. (2003). The cell cycle of pathogenic fungi: target for drugs. Progress in cell cycle Research, 5, 81-90.

5. Choi,G.H., Marek, E.T., Schardl, C.L., Richey, M.G., Chang, S. and Smith, D.A. (1990) A stressresponsive gene in Fusarium spp. J. Bacteriol. 172: 4522-4528.

6. Collee, J. G., Duguid, I. P., Fraser, A. G., \& Marmion, B. P. (1996). Enterobacteriaceae-Escherichia, Klebsiella, Proteus and other genera. 137-149. Collee, JG, JP Duguid, AG Froser and BP Marmion (ed 5.), Practical medical microbiology, 14th eds. Hong Kong: Mackie and Mac Corthey, Lonyman Group UK Ltd.

7. Dąbrowska, I., Dworecka-Kaszak, B., \& Brillowska-Dąbrowska, A. (2014). The use of a one-step PCR method for the identification of Microsporum canis and Trichophyton mentagrophytes infection of pets. Acta Biochimica Polonica, 61(2).
8. Effendy, I., Lecha, M., Feuilhade de Chauvin, M., Di Chiacchio, N., \& Baran, R. (2005). Epidemiology and clinical classification of onychomycosis. Journal of the EuropeanAcademy of Dermatology and Venereology, 19, 8-12.

9. Ellis, D. H. (1999). Evaluation of the sensititre Yeast one microtitre panel, Etest and Neo - sensitab disk methods of antifungal susceptibility tests against 4 - reference yeast.Abstract MP3 , $249^{\text {th }}$ IUMS International Congress of Mycology .Sydney, August>

10. Grumbt, M., Monod, M., Yamada, T., Hertweck, C., Kunert, J., \& Staib, P. (2013). Keratin degradation by dermatophytes relies on cysteine dioxygenase and a sulfite efflux pump. Journal of Investigative Dermatology, 133(6), 1550-1555.

11. Gunalan, S., Sivaraj, R., \& Rajendran, V. (2012). Green synthesized $\mathrm{ZnO}$ nanoparticles against bacterial and fungal pathogens. Progress in Natural Science: Materials International, 22(6), 693-700.

12. Hamouda, T., Myc, A., Donovan, B., Shih, A. Y., Reuter, J. D., \& Baker, J. R. (2001). A novel surfactant nanoemulsion with a unique non-irritant topical antimicrobial activity against bacteria, enveloped viruses and fungi. Microbiological research, 156(1), 17.

13. Jha, B. K., Murthy, S. M., \& Devi, N. L. (2012). Molecular identification of dermatophytosis by polymerase chain reaction (PCR) and detection of source of infection by restricted fragment length polymorphism (RFLP). Journal of College of Medical Sciences-Nepal, 8(4), 7-15

14. Jones, N., Ray, B., Ranjit, K. T., \& Manna, A. C. (2008). Antibacterial activity of $\mathrm{ZnO}$ nanoparticle suspensions on a broad spectrum of microorganisms. FEMS microbiology letters, 279(1), 71-76

15. Kanitakis, J., Karayannopoulou, G., Lanzetta, M., \& Petruzzo, P (2014). Graft vasculopathy in the skin of a human hand allograft: implications for diagnosis of rejection of vascularized composite allografts. Transplant International, 27(11), e118-e123.

16. Kim, K. J., Sung, W. S., Moon, S. K., Choi, J. S., Kim, J. G., \& Lee, D. G. (2008). Antifungal effect of silver nanoparticles on dermatophytes. J Microbiol Biotechnol, 18(8), 1482-1484.

17. Lee, H. J., Yeo, S. Y., \& Jeong, S. H. (2003). Antibacterial effect of nanosized silver colloidal solution on textile fabrics. Journal of Materials Science, 38(10), 2199-2204

18. McGinnis, M. R. (1980). Yeast identification. Laboratory Handbook of Medical Mycology, 337-411

19. McGinnis, M.R. (1980). Laboratory hand book of medical mycology. Acadmic press., New York. P: 356.

20. Pandey, A., \& Pandey, M. (2013). Isolation and characterization of dermatophytes with tinea infections at Gwalior ( $\mathrm{mp})$, India. Int J Pharm Sci Invent, 2(2), 5-8.

21. Piérard, G. E., Arrese, J. E., \& Piérard-Franchimont, C. (1996) Treatment and prophylaxis of tinea infections. Drugs, 52(2), 209224.

22. Shalaby, M. F. M., El-din, A. N., \& El-Hamd, M. A. (2016). Isolation, identification, and in vitro antifungal susceptibility testing of dermatophytes from clinical samples at Sohag University Hospital in Egypt. Electronic physician, 8(6), 2557.

23. Sondi, I., \& Salopek-Sondi, B. (2004). Silver nanoparticles as antimicrobial agent: a case study on E. coli as a model for Gramnegative bacteria. Journal of colloid and interface science, 275(1), 177-182

24. Wiegand, P., Bajanowski, T., \& Brinkmann, B. (1993). DNA typing of debris from fingernails. International journal of legal medicine, 106(2), 81-83

25. Williams, J. G., Kubelik, A. R., Livak, K. J., Rafalski, J. A., \& Tingey, S. V. (1990). DNA polymorphisms amplified by arbitrary primers are useful as genetic markers. Nucleic acids research, 18(22), 6531-6535.

26. Zhang, R., Piao, M. J., Kim, K. C., Kim, A. D., Choi, J. Y., Choi, J., \& Hyun, J. W. (2012). Endoplasmic reticulum stress signaling is involved in silver nanoparticles-induced apoptosis. The international journal of biochemistry \& cell biology, 44(1), 224232 